ARTICLE

https://doi.org/10.1038/s41467-020-15101-6

\title{
The nature of deep overturning and reconfigurations of the silicon cycle across the last deglaciation
}

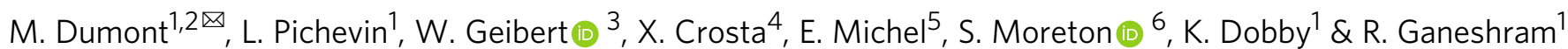

Changes in ocean circulation and the biological carbon pump have been implicated as the drivers behind the rise in atmospheric $\mathrm{CO}_{2}$ across the last deglaciation; however, the processes involved remain uncertain. Previous records have hinted at a partitioning of deep ocean ventilation across the two major intervals of atmospheric $\mathrm{CO}_{2}$ rise, but the consequences of differential ventilation on the $\mathrm{Si}$ cycle has not been explored. Here we present three new records of silicon isotopes in diatoms and sponges from the Southern Ocean that together show increased Si supply from deep mixing during the deglaciation with a maximum during the Younger Dryas (YD). We suggest Antarctic sea ice and Atlantic overturning conditions favoured abyssal ocean ventilation at the YD and marked an interval of Si cycle reorganisation. By regulating the strength of the biological pump, the glacial-interglacial shift in the $\mathrm{Si}$ cycle may present an important control on Pleistocene $\mathrm{CO}_{2}$ concentrations.

\footnotetext{
${ }^{1}$ School of Geosciences, University of Edinburgh, Edinburgh, UK. ${ }^{2}$ School of Earth and Environmental Sciences, University of St Andrews, St Andrews, UK ${ }^{3}$ Alfred Wegener Institute, Bremerhaven, Germany. ${ }^{4}$ UMR 5805 EPOC, Universite de Bordeaux, Bordeaux, France. ${ }^{5}$ Laboratoire des Sciences du Climat et I'Environnement/Institute Pierre-Simon Laplace, Laboratoire CNRS-CEA-UVSQ, Gif-sur-Yvette, France. ${ }^{6}$ Scottish Universities Environmental Research Centre, East Kilbride, UK. ${ }_{\text {email: }}$ md76@st-andrews.ac.uk
} 
T he last deglaciation (10,000-18,000 years ago, $10-18 \mathrm{ka})$ was an interval of dramatic climatic change characterised by rise in atmospheric $\mathrm{CO}_{2}$ concentrations by $80-90 \mathrm{ppm}^{1}$. A well-accepted mechanism links the rise in $\mathrm{CO}_{2}$ to a global reorganisation of the ocean overturning circulation leading to an increase in deep ocean ventilation across the deglaciation ${ }^{2,3}$. Overturning in the Southern Ocean is thought to have played a key role with respect to the deglacial rise in $\mathrm{CO}_{2}$ in part because it is where many of the world's water masses outcrop today ${ }^{4}$. Hence, this is a region where deep ocean ventilation is moderated ${ }^{5-8}$ and where nutrients are redistributed via intermediate waters to the low latitudes controlling the strength of carbon drawdown into the ocean via the biological pump ${ }^{9,10}$. As such, elucidating how the ocean circulation changes across deglacial transitions is important for our understanding of the causes of glacial-interglacial $\mathrm{CO}_{2}$ variability.

Recent studies have noted basin-scale or inter-basin heterogeneities in the onset of deglacial ventilation of the ocean interior that previously had been regarded as a uniform process of wholeocean change leading to the observed rise in atmospheric $\mathrm{CO}_{2}$. For example, $\delta^{13} \mathrm{C}, \delta^{18} \mathrm{O}$ and radiocarbon studies of benthic foraminifera have revealed differential termination onsets between the Atlantic, Pacific and Indian Oceans ${ }^{11-15}$. Others have shown a difference in ventilation timing with depth within basins ${ }^{15-19}$. The influence of these asynchronous circulation changes on the redistribution of nutrients such as silicic acid (DSi) has not been explored. The importance of DSi in particular lies in its influence over phytoplankton community composition. A supply of DSi-rich waters favours the proliferation of diatoms $s^{20,21}$ that efficiently export organic carbon from the ocean surface $^{22}$ without exporting alkalinity. This promotes a greater drawdown of $\mathrm{CO}_{2}$ into the ocean by increasing the $\mathrm{C}_{\text {org }}: \mathrm{CaCO}_{3}$ rain ratio 23,24 .

The hypothesised changes in ocean circulation and overturning may have impacted on the distribution of DSi differently to carbon. Due to the slower remineralisation rate of biogenic silica (opal) relative to organic carbon during particle settling, the DSi maximum lies deeper in the water column ${ }^{25}$. Therefore, the supply of DSi to the surface ocean via upwelling relative to carbon and other nutrients should be particularly sensitive to changes in deep overturning and mixing. Silicon cycling within the ocean may be reconstructed by the analysis of silicon isotopes within the frustules and spicules of diatoms and siliceous sponges.

Isotopic fractionation occurs during the uptake of DSi by diatoms, discriminating against the heavier isotopes with a consistent average fractionation factor of $-1.1 \% 0^{26,27}$. As the pool of available DSi is depleted both the isotopic composition of diatom biogenic silica $\left(\delta^{30} \mathrm{Si}_{\text {diat }}\right)$ and the remaining DSi become isotopically heavier. Hence, $\delta^{30} \mathrm{Si}_{\text {diat }}$ can be used as a proxy for the relative utilization of the available DSi pool ${ }^{26,28}$. Assuming no significant changes in dissolution, opal accumulation can be used as a proxy for the absolute uptake of DSi by diatoms. Changes in DSi supply to the surface ocean can be inferred from the changes in relative depletion $\left(\delta^{30} \mathrm{Si}_{\text {diat }}\right)$ compared to those of the absolute uptake indicated by the opal accumulation.

The silicon isotopic composition of sponges $\left(\delta^{30} \mathrm{Si}_{\text {sponge }}\right)$ has been shown to be dependent on concentration and isotopic composition of the ambient DSi. Sponges preferentially incorporate the lighter silicon isotopes into their spicules with a greater fractionation occurring under higher DSi concentrations $s^{29,30}$. Hence, $\delta^{30} \mathrm{Si}_{\text {sponge }}$ records can be used to infer the changes in the DSi content within the deep ocean. Since the deep ocean supplies DSi to the Southern Ocean surface, the $\delta^{30} \mathrm{Si}_{\text {sponge }}$ and $\delta^{30} \mathrm{Si}_{\text {diat }}$ records can be used together to infer whether the deep ocean DSi content could be influencing the supply to the surface ocean.
Using sediment records of silicon isotopes, we document how changes in circulation across the deglaciation influenced the input of DSi to the surface of the Southern Ocean. Further, we demonstrate that greater input of DSi to the Southern Ocean increased the transport of DSi from the Southern Ocean to low latitudes, fertilizing diatom production there. Finally, we propose that the poor ventilation and greater stratification of the ocean during glacial periods decoupled DSi and carbon distributions leading to an accumulation of DSi in the deep ocean. We suggest that this proposal provides further insight into how the biological pump moderates atmospheric $\mathrm{CO}_{2}$ across glacial-interglacial cycles.

\section{Results}

Diatom-based proxies. $\delta^{30} \mathrm{Si}_{\text {diat }}$ and opal accumulation records were constructed from three cores (MD84-551: $55.01^{\circ} \mathrm{S}, 73.17^{\circ} \mathrm{E}$, $2230 \mathrm{~m}$ water depth. MD88-773: 52.90 ${ }^{\circ} \mathrm{S}, 109.87^{\circ} \mathrm{E}, 2460 \mathrm{~m}$ water depth. MD88-772: $50.02^{\circ}$ S, $104.90^{\circ} \mathrm{E}, 3310 \mathrm{~m}$ water depth) located in the Antarctic Zone (AZ) and Polar Front Zone (PFZ) of the Indian sector of the Southern Ocean (Fig. 1). The DSi supplied to these zones is sourced from circumpolar deep water ${ }^{31,32}$, which upwells within the AZ and delivers DSi to the PFZ by Ekman transport.

The $\delta^{30} \mathrm{Si}_{\text {diat }}$ records of the three cores (Fig. 2) display an overall LGM - to - Holocene $\delta^{30} \mathrm{Si}_{\text {diat }}$ increase of $0.65-0.86 \%$. This magnitude of glacial-interglacial $\delta^{30} \mathrm{Si}_{\text {diat }}$ change is characteristic of Southern Ocean sediment records ${ }^{28,33-35}$ and has been attributed to higher LGM dust-borne iron fluxes causing diatoms to reduce their DSi demand ${ }^{36}$. It has been argued that changes in diatom species composition within record may drive changes in $\delta^{30} \mathrm{Si}_{\text {diat }}{ }^{37}$. Diatom assemblage data (Supplementary Note 4 and Supplementary Figs. 6 and 7) does not support a significant species component that can explain the ${ }^{30} \mathrm{Si}_{\text {diat }}$ variability across all three records.

The opal accumulation records from MD84-551 and MD88773 were ${ }^{230} \mathrm{Th}$-normalised to correct for sediment focusing ${ }^{38}$. ${ }^{230} \mathrm{Th}$ data were not available for MD88-772 so opal mass accumulation rate (MAR) was determined using the dry bulk densities and sedimentation rates. However, it was noted in a previous study using a collection of sediment records from the Indian sector of the Southern Ocean, including MD88-773, that although MAR cannot be used quantitatively, the overall glacialinterglacial patterns observed in MAR records remained largely the same after ${ }^{230} \mathrm{Th}$-normalisation ${ }^{39}$. Preservation changes are not corrected for here, but Dezileau et al. ${ }^{39}$ showed that changes in preservation were not important drivers of opal accumulation variability in the region over the last $40 \mathrm{ka}$.

Supply of DSi to the Southern Ocean surface. The initial $\delta^{30} \mathrm{Si}_{\text {diat }}$ rise observed from the LGM through the first Antarctic warming interval associated with Heinrich Stadial 1 (HS1) $(\sim 23-15 \mathrm{ka})$ coincides with a reduction in dust-borne iron flux ${ }^{40,41}$ and may represent a gradual progression towards iron limitation, favouring an increase in the DSi demand by the diatom community ${ }^{36}$. Together the opal accumulation and $\delta^{30} \mathrm{Si}_{\text {diat }}$ records provide little indication that DSi supply markedly changed across this interval. Globally, gradients between $\delta^{30} \mathrm{Si}_{\text {diat }}$ records (Fig. 3a) display very little change across HS1, suggesting that the relative utilisation of DSi between sites and any regional differences in supply of DSi changed little over this interval.

After the early deglacial rise in $\delta^{30} \mathrm{Si}_{\text {diat }}$ within all three cores, MD84-551 and MD88-773 exhibit a period of maximum $\delta^{30} \mathrm{Si}_{\text {diat }}$ coinciding with the Antarctic Cold Reversal (ACR). Unfortunately, no ${ }^{30} \mathrm{Si}_{\text {diat }}$ data are available for MD88-772 from this interval. Maximum $\delta^{30} \mathrm{Si}_{\text {diat }}$ is reached when the dust fluxes fall to 


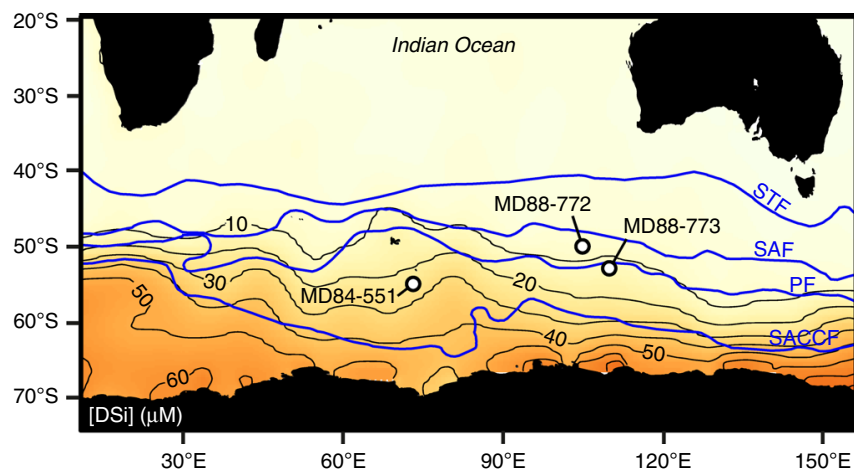

C

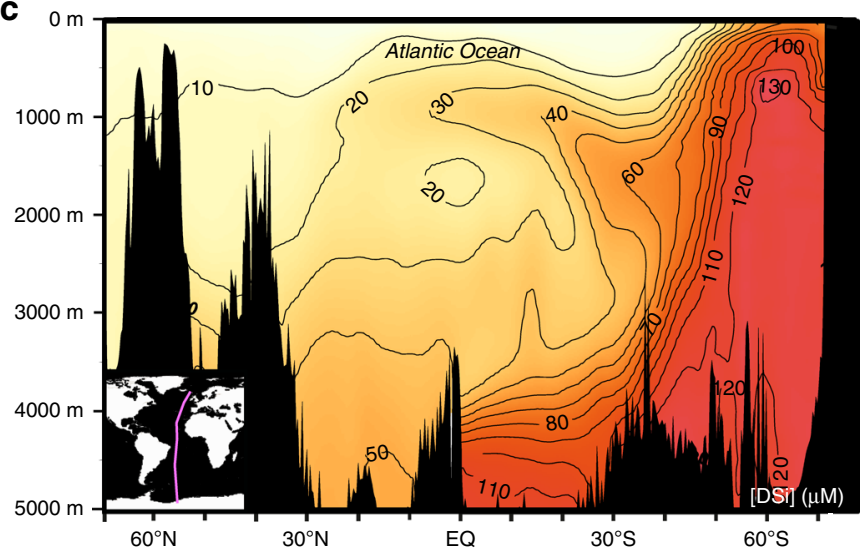

b

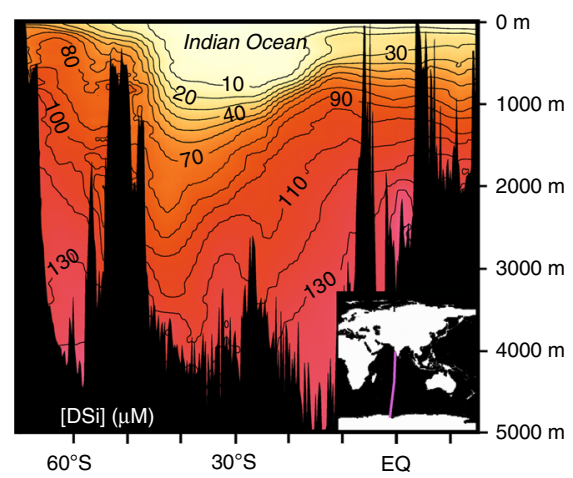

d

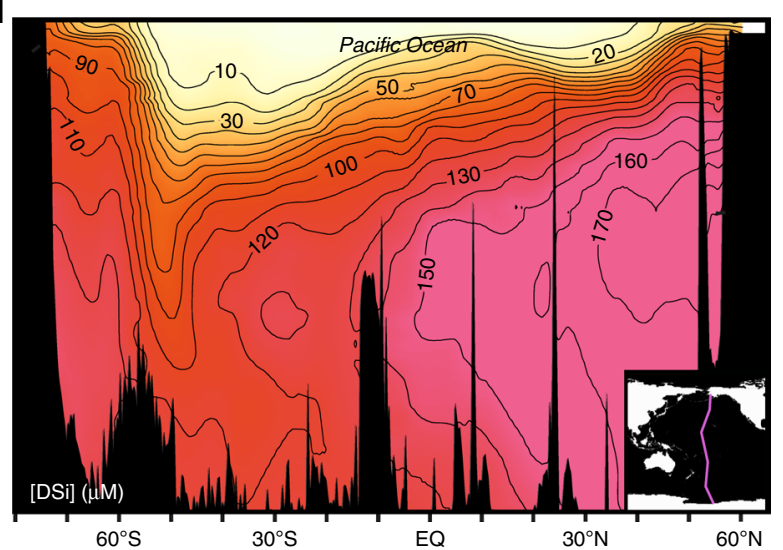

Fig. 1 The DSi distribution surrounding the core locations and within the major oceanic basins. a DSi concentrations in the surface ocean (10 $\mathrm{m}$ depth) across the Indian Sector. Front locations including the southern Antarctic circumpolar current front (SACCF), polar front (PF), Subantarctic front (SAF) and Subtropical front (STF) (blue lines) are according to Orsi et al. ${ }^{92}$ MD84-551 and MD88-773 lie within the Antarctic Zone (AZ), the region of ocean south of the PF. MD88-772 lies in the Polar Frontal Zone (PFZ), which is delineated by the PF to the south and the SAF to the north. b-d Show profiles of [DSi] within the Indian, Atlantic and Pacific Oceans, respectively. Transect paths are given in within the inset of each panel. [DSi] data from the World Ocean Atlas 201393, gridded using Ocean Data View ${ }^{94}$.

a minimum suggesting comparable relative uptake of the DSi pool at the ACR and Holocene. However, the low opal fluxes in the two AZ cores suggest DSi supply over the ACR was low.

The $\delta^{30} \mathrm{Si}_{\text {diat }}$ converge towards markedly light values during the YD in all three records, suggesting the relative utilisation of DSi was low across this interval. The pronounced $\delta^{30} \mathrm{Si}_{\text {diat }}$ convergence during the YD cannot be explained by an episode of iron fertilisation as it does not correspond to regional reconstructions of dust flux ${ }^{40}$ nor reconstructions of local lithogenic flux (see Supplementary Note 2 and Supplementary Fig. 4). Any influence of sea ice at the core locations on the fractionation of $\mathrm{Si}$ isotopes ${ }^{42}$ is unlikely to have been important based on regional reconstructions of sea ice cover (see Supplementary Note 3 and Supplementary Fig. 5).

Opal accumulation records indicate that absolute silica export during the YD was similar or greater than during the Holocene (Fig. 2) ${ }^{39,43}$. Therefore, we suggest the $\delta^{30} \mathrm{Si}_{\text {diat }}$ minimum reflects an overwhelming DSi supply greater than that during the Holocene epoch. Such a pulse of DSi supply is supported by the compilation of Southern Ocean $\delta^{30} \mathrm{Si}_{\text {diat }}$ records (Fig. 3a). The pronounced $\delta^{30} \mathrm{Si}_{\text {diat }}$ minimum during the $\mathrm{YD}$ is a common feature in Southern Ocean records (see compilation Fig. 3a) and the values tend to converge towards $\sim 1 \%$ in all but one record during this interval. Such global uniformity implies a flattening of the meridional DSi gradients at the YD driven by a large-scale supply of DSi to the Southern Ocean. The large influx of DSi overwhelmed the increasing DSi demand levied on the diatom community as the dust-borne iron supply reached a minimum by the end of the ACR (Fig. 2a) ${ }^{40}$. This enhanced DSi supply coincides with a breakdown of the vertical DSi gradient in the upper Southern Ocean as indicated by the convergence of radiolarian silicon isotope $\left(\delta^{30} \mathrm{Si}_{\text {rad }}\right)$ and $\delta^{30} \mathrm{Si}_{\text {diat }}$ records (Fig. 3b $)^{44}$.

The DSi supply to the Southern Ocean during the YD can be quantified by applying the mass balance model setup adapted from Beucher et al. ${ }^{33}$ for the Antarctic and Subantarctic that evaluates the budgets of DSi, opal export and silicon isotopes based on available data (see Supplementary Note 5 and Supplementary Figs. 8-11). In this case we use the averages of the Antarctic (AZ) and Subantarctic (PFZ \& SAZ) $\delta^{30} \mathrm{Si}_{\text {diat }}$ values of the YD (12.5-11.8 ka), estimated as 1.06 and $1.27 \%$, respectively, to constrain the model. A solution to the mass balance model is presented in Fig. 4, assuming the same opal exports and isotope system models as the modern ocean (open system Antarctic, closed system Subantarctic, see Supplementary Note 5 for justification). The assumption that opal export was the same during the YD relative to the modern was made for simplicity, however, many Southern Ocean records show increased opal flux at the YD, suggesting opal exports were greater. Consequently, our mass balance estimations of the DSi supply to and export from the Southern Ocean are likely underestimates.

Using the mass balance model, we estimate that the concentration of DSi in deep waters supplying Antarctic mixed layer during the YD was $84 \mu \mathrm{M}$ (Fig. 4), an elevation of $18 \mu \mathrm{M}$ $(27 \%)$ relative to the Holocene $(65 \mu \mathrm{M})$. This additional supply went unutilised thus increasing the export of DSi to the low latitudes ${ }^{45,46}$. 
a

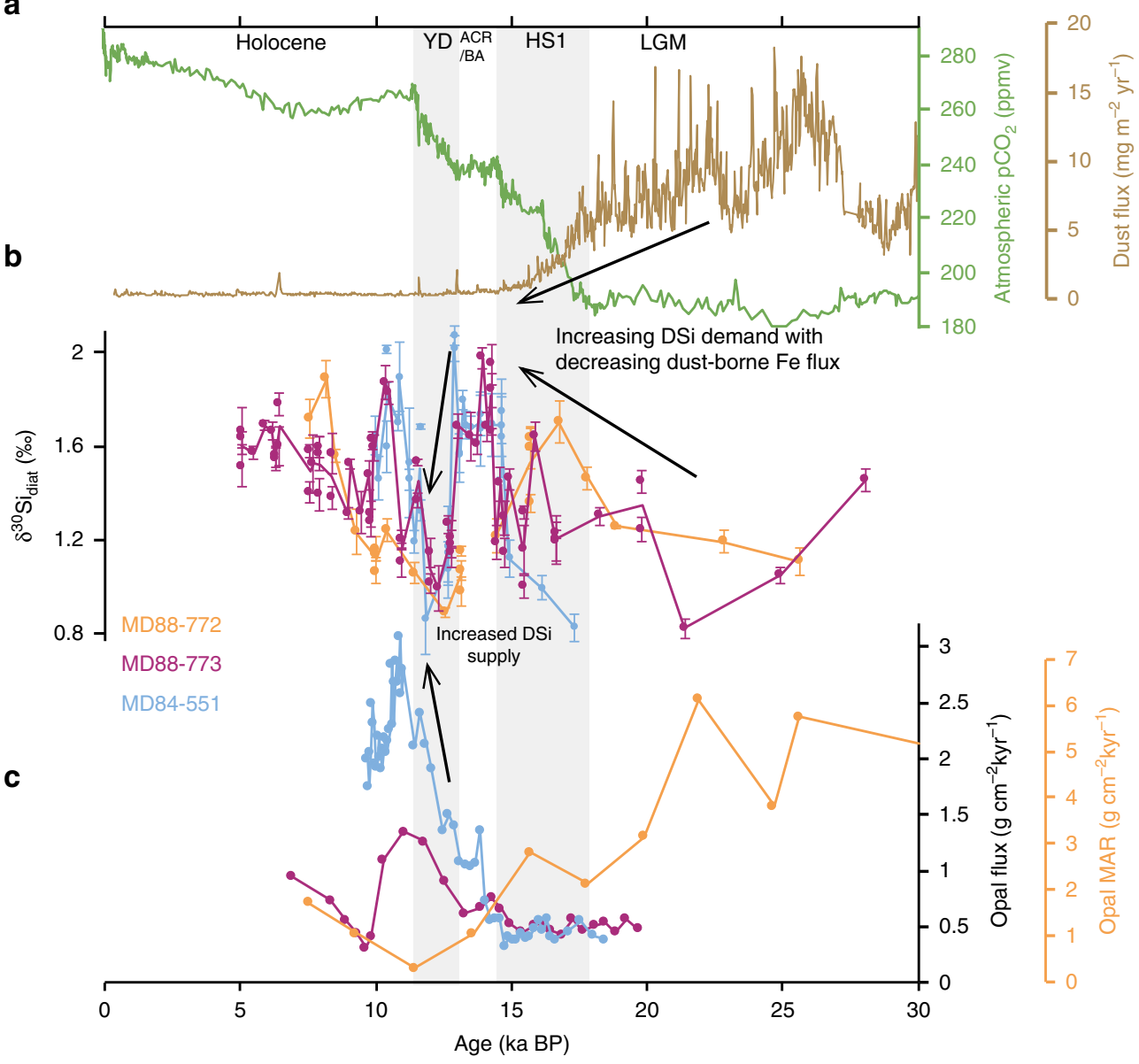

Fig. 2 Deglacial $\boldsymbol{\delta}^{\mathbf{3 0}} \mathbf{S i}_{\text {diat }}$ and opal records from the three Indian sector cores. a Atmospheric $\mathrm{CO}_{2}{ }^{1}$ and Antarctic dust flux ${ }^{40}$ recorded in EPICA Dome C. b $8^{30} \mathrm{Si}_{\text {diat }}$ data from MD84-551, MD88-773 and MD88-772 with $\pm 1 S E$. c ${ }^{230}$ Th-normalised opal flux records from MD84-551 and MD88-773 (230Thnormalisation data from Francois et al. ${ }^{80}$,) and opal mass accumulation rate (MAR) from MD88-772.

Deep Si mixing recorded by sponges. $\mathrm{A} \delta^{30} \mathrm{Si}_{\text {sponge }}$ record has been produced from MD84-551 and is compared with similar records from the Pacific and Atlantic sectors ${ }^{47}$ in order to reconstruct zonal changes in deep DSi gradients across the deglaciation (Fig. 3d). Together the three records display a strong gradient in $\delta^{30} \mathrm{Si}_{\text {sponge }}$ during the LGM, with the more negative Pacific $\delta^{30} \mathrm{Si}_{\text {sponge }}$ values suggesting an accumulation of DSi in that basin relative to the Holocene ${ }^{47}$. The DSi concentration and isotopic composition of modern circumpolar deep water is largely uniform between sectors of the Southern Ocean ${ }^{48,49}$. The $\delta^{30} \mathrm{Si}_{\text {sponge }}$ records shown here suggest that zonal DSi gradients were expanded and the concentration of DSi content of the Pacific sector was greater during the LGM relative to the Holocene.

During HS1 the Indian record (MD84-551) converges toward the Atlantic record (ODP177-1089) and the records of all three basins converge following the ACR. This suggests that transition towards homogenisation of DSi between the sectors occurred in two stages: First, the Atlantic sector and at least a portion of the Indian sector zonally homogenised during HS1 followed by the mixing of all three sectors at the YD.

\section{Discussion}

The broadening of deep $\delta^{30} \mathrm{Si}_{\text {sponge }}$ gradients in the Southern Ocean during the LGM and the simultaneous collapse of these gradients along with those recorded in Southern Ocean $\delta^{30} \mathrm{Si}_{\text {diat }}$ records indicates DSi accumulated within the Pacific during the LGM and was subsequently released at the YD via upwelling in the Southern Ocean. We suggest that the fate of this DSi pulse was to be incorporated into intermediate waters and transported to lower latitudes. This is corroborated by $\delta^{30} \mathrm{Si}_{\text {sponge }}$ data from the Brazilian margin ${ }^{45}$ that suggest a pulse of DSi-rich waters entered intermediate depths during the YD. The northward transport of high DSi waters may have promoted the enhanced diatom productivity observed at this time within low latitude upwelling regions 46,50 .

The interpretation given above suggests that the breakdown of stratification in the deep Pacific was delayed until the late deglaciation. Incomplete ventilation of the Pacific until the late deglaciation is also suggested by benthic foraminifera $\delta^{13} \mathrm{C}$ records in the southwest Pacific ${ }^{18,19}$, four of which are presented in Fig. 3e. $\delta^{13} \mathrm{C}$ reflects a balance between surface ocean processes (photosynthesis and air-sea gas exchange) that tend to increase $\delta^{13} \mathrm{C}$, and the deep ocean processes (isolation from the atmosphere and remineralisation of organic carbon) that tend to decrease $\delta^{13} \mathrm{C}$. Thus, the expanded gradient between the shallow record (87 JPC) and the two deeper records (79 JPC and 41 JPC) indicates that vertical mixing was reduced at the $\mathrm{LGM}^{18}$. The increase in $\delta^{13} \mathrm{C}$ within the intermediate depth core (79 JPC) during the HS1 interval and its convergence towards the shallower ocean record (87 JPC) suggests that chemical gradients were broken down in the upper $1165 \mathrm{~m}$ of the southwest Pacific during HS1 due to ventilation of the intermediate ocean. This agrees well with radiocarbon records from Siani et al. ${ }^{7}$ that suggest ventilation of the south-eastern Pacific down to $1536 \mathrm{~m}$ upon the first warming interval. 

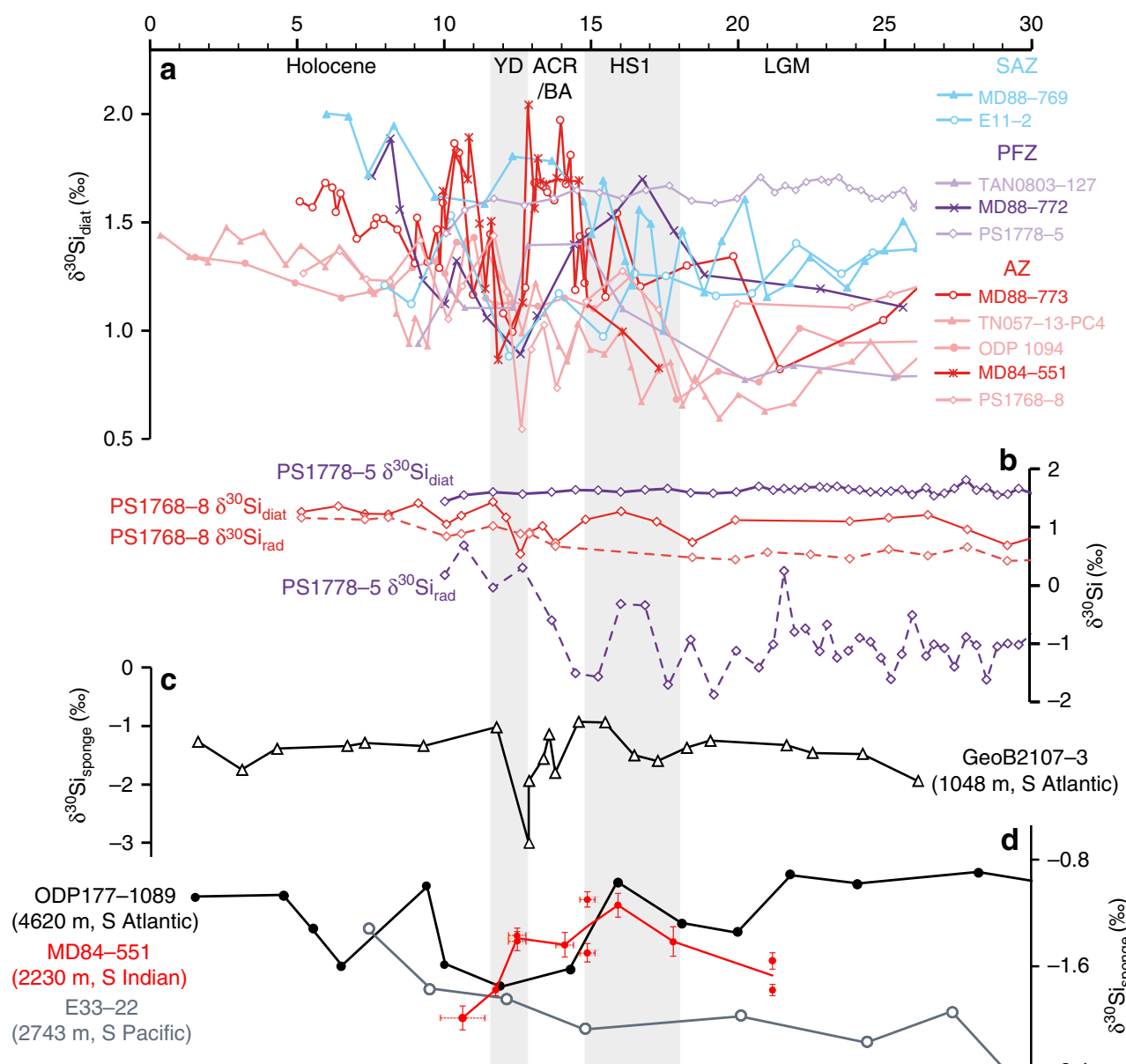

(2743 m, S Pacific)

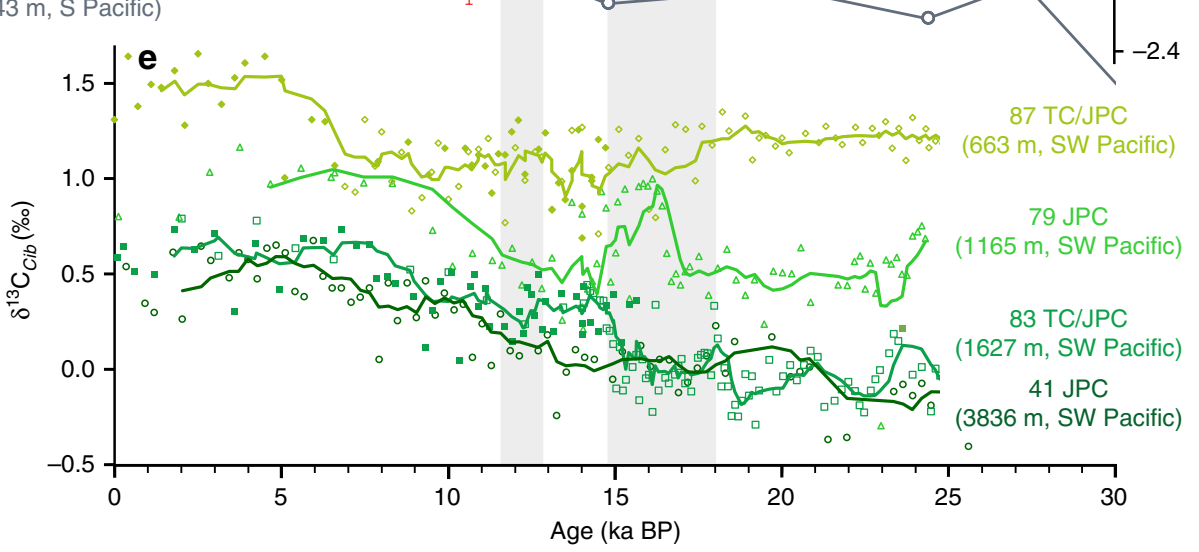

Fig. 3 A global compilation of silicon isotope data demonstrating the reorganisation of the DSi distribution across the last deglaciation. a Diatom silicon isotope $\left(\delta^{30} \mathrm{Si}_{\text {diat }}\right.$ ) records from the Antarctic Zone (red), Polar Front Zone (purple) and Subantarctic Zone (blue). MD88-76933. E11-2 \& ODP109435. TAN0803-12795. PS1778-5 \& PS1768-844. TN057-13-PC4 $4^{34}$. b Diatom $\left(\delta^{30} \mathrm{Si}_{\text {diat }}\right.$ ) and radiolarian $\left(\delta^{30} \mathrm{Si}_{\text {rad }}\right)$ silicon isotope records from PS1768-8 and PS1778-5 in the Atlantic sector ${ }^{44}$ reconstructing changes in the vertical DSi gradient in the upper Southern Ocean. c A sponge silicon isotope record $\left(\delta^{30} \mathrm{Si}_{\text {sponge }}\right.$ ) from $1048 \mathrm{~m}$ in the South Atlantic ${ }^{45}$ recording changes in DSi content within intermediate waters. $\mathbf{d} \delta^{30} \mathrm{Si}_{\text {sponge }}$ record from MD84-551 accompanied by records from the south Atlantic and south Pacific ${ }^{47}$. Vertical error bars display $\pm 1 S E$. Horizontal error bars, where present, represent the age range of the samples used to produce the given data point. Together these $\delta^{30} \mathrm{Si}_{\text {sponge }}$ records demonstrate the deglacial changes in deep ocean DSi gradients. e Four benthic foraminiferal (Cibicidoides wuellerstorfi) $\delta^{13} \mathrm{C}$ records from the southwest Pacific ${ }^{18}$ highlighting the timing of ventilation changes in the Pacific across the last deglaciation. Solid and open symbols represent samples from jumbo piston and trigger cores, respectively. A map depicting the locations of all cores used in this figure can be found in Supplementary Fig. S1.

The minimal response in deeper Pacific records such as $41 \mathrm{JPC}$ at that time suggests that the vertical mixing did not reach to abyssal depths where DSi concentrations are highest. This partial ventilation of the Pacific Ocean during HS1 is also supported by studies that demonstrate both delayed ventilation in the deep Pacific 17,18 and a discrepancy in the onset of ventilation between basins ${ }^{11,13,14}$.
On the other hand, several radiocarbon records indicate that the deep Atlantic ${ }^{5,6}$ and at least some of the deep Pacific ${ }^{15,51,52}$ became ventilated at HS1 rather than just during the YD. This is also supported by $\mathrm{Nd}$ data that have been interpreted to as indicating enhanced production of southern-sourced bottom waters at that time $e^{52,53}$. 

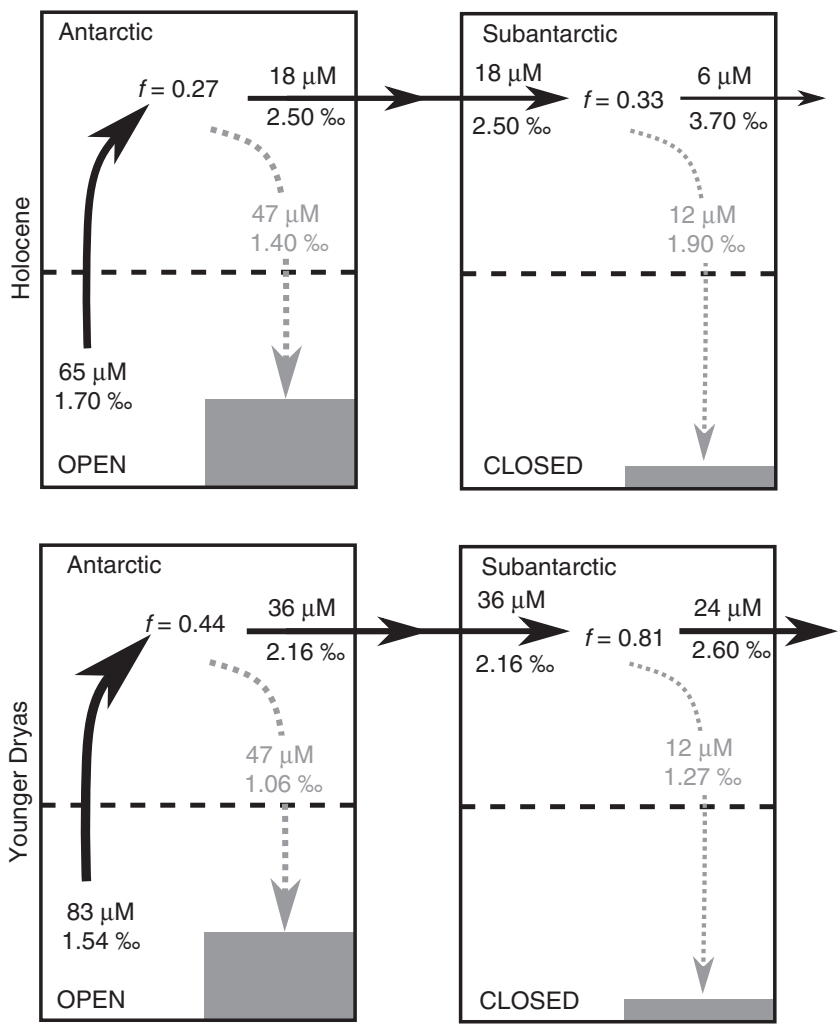

Fig. 4 Solutions to the mass balance model for Si cycling in the Southern Ocean during the Holocene (top) and Younger Dryas (bottom). In each of the reconstructions an open and closed isotope system models were applied to the Antarctic and Subantarctic, respectively. Black and grey arrows and text denote the transfer of DSi and opal, respectively. Bold data are those extracted from the literature and available data. The remaining data have been calculated from the simple mass balance model. The term, $f$, is the fraction of the available DSi pool remaining after utilization by diatoms. More details on the construction of this model can be found in Supplementary Note 5, along with the justification for the isotope system models applied here.

To aid in the interpretation of these studies we shall use the schematic of global overturning circulation in Fig. 5. Each of the panels in Fig. 5 illustrate a simplified two-dimensional view of ocean circulation based on the work by Ferrari et al. ${ }^{54}$, with the lower circulatory cell (white arrows) representing overturning in the Pacific, Southern and Indian Oceans and the upper circulatory cell representing the Atlantic overturning. It has been shown that during the LGM the boundary between the two overturning cells shoaled ${ }^{54,55}$, the Southern Ocean wind-driven mixing was stifled by expanded sea ice cover ${ }^{56}$ and diapycnal mixing was reduced due to the production of denser bottom waters ${ }^{57}$ and the shoaling of the boundary water masses above important bathymetric mixing depths ${ }^{54}$. Together the processes given above may have chemically isolated the deeper portions of the ocean from the surface favouring the trapping of DSi within the lower cell. Reduced diapycnal mixing ${ }^{54}$ and penetration of Atlantic deep waters $^{14}$ during the LGM could have also inhibited mixing between deep waters separated by large topographic features such as the Drake Passage, Kerguelen Plateau and Macquerie Rise ${ }^{14,58}$. DSi may be more sensitive to the formation of inter-basin chemical gradients relative to other nutrients due to its deeper profile. Zonal gradients are not depicted in Fig. 5 for simplicity.

During HS1 the initiation of deglacial sea ice retreat ${ }^{59-61}$ and southward westerly wind migration ${ }^{62}$ is thought to have induced greater overturning in the Southern Ocean ${ }^{6,52}$. This could have permitted an increase in Antarctic bottom water production ${ }^{52,53}$ and a greater exchange of carbon between the deep ocean and atmosphere thus decreasing deep ocean radiocarbon reservoir ages $^{5,6}$. However, an incomplete loss of sea ice from the Southern Ocean may have inhibited some of the ocean-atmosphere carbon exchange ${ }^{63}$, maintaining a poorly ventilated signal in sinking Pacific $\mathrm{AABW}^{52}$. We propose that the invigorated overturning in the Southern Ocean during HS1 released some of the deeply sequestered DSi to the surface ocean, indeed many of the more southerly AZ $\delta^{30} \mathrm{Si}_{\text {diat }}$ records indicate utilization was low during HS1 despite the decline in dust flux, suggesting DSi supply had risen relative to the LGM (Fig. 3a) ${ }^{34,35}$. However, the deep glacial ocean DSi gradients largely remained intact through HS1 (Fig. $3 \mathrm{~d})^{47}$ along with the deep $\delta^{13} \mathrm{C}$ gradients (Fig. 3e ${ }^{18}$. Hence, we suggest that despite the greater Southern Ocean overturning during HS1, the deep ocean remained stratified keeping DSi trapped within the lower overturning cell.

At the Bølling-Allerød (BA)/ACR it is thought that the AMOC strengthened ${ }^{64,65}$, which could have contributed to the weakening of vertical and inter-basin chemical gradients ${ }^{14}$. However, the return to stratified conditions in the Southern Ocean surface in response to a reversal in winter sea ice coverage ${ }^{59}$ may have limited the redistribution of DSi between the two circulatory cells.

A resumption of sea ice coverage $\operatorname{loss}^{59}$ and a southward shift of westerlies ${ }^{62}$ at the YD could have enabled vertical mixing to strengthen in the Southern Ocean leading to the tapping of deeper, DSi-rich waters by upwelling circumpolar water ${ }^{66}$. This may have been supported by the moderate weakening of the AMOC during the YD in contrast to the intensely weakened AMOC at $\mathrm{HS}^{64}$, enabling greater deep mixing between the two overturning cells. We suggest that together these processes initiated a massive redistribution of DSi from the deep ocean into intermediate waters ${ }^{45}$.

The ventilation scenario depicted in Fig. 5 has important implications for the redistribution of chemical species such as DSi that have a deeper remineralisation profile. We suggest that the deep flushing of DSi from the abyssal ocean during the late deglaciation is an important process that helps reconfigure both the carbon storage within the oceans ${ }^{52}$ as well as the marine Si cycle between glacial and interglacial states.

This new proposal, which we term the Abyssal Silicon Hypothesis, envisions the massive redistribution of DSi from the abyss during the second phase of $\mathrm{CO}_{2}$ increase (YD) marking the reorganisation of the $\mathrm{Si}$ cycle between glacial and interglacial periods. This differs from previous hypotheses that have attempted to describe how silicon cycling is altered across glacialinterglacial cycles. One such hypothesis is the Silicic Acid Leakage Hypothesis, which suggests that higher DSi delivery to the low latitudes during glacials due to an iron-regulated reduction in DSi utilization in the Southern Ocean ${ }^{36,67}$ enhanced diatom production there and resulted in net atmospheric $\mathrm{CO}_{2}$ drawdown. However, this hypothesis does not fully account for the changes in deep circulation and sequestration of DSi in the deep ocean that would in fact act against a greater delivery of DSi to low latitudes during the LGM. Furthermore, we demonstrate that when leakage of DSi from the Southern Ocean is at a maximum during the deglaciation, dust fluxes to the Southern Ocean were not significantly different from today (Fig. 2a). Hence, the Abyssal Silicon Hypothesis places a greater importance on deep diapycnal mixing and overturning in driving the redistribution of DSi across the global ocean.

The Abyssal Silicon Hypothesis also differs from the Silicic Acid Ventilation Hypothesis ${ }^{30}$, which argues that the redistribution of DSi occurs primarily during deglaciations but with little overall change between glacial and interglacial states. Firstly, an important difference in light of the high-resolution records 

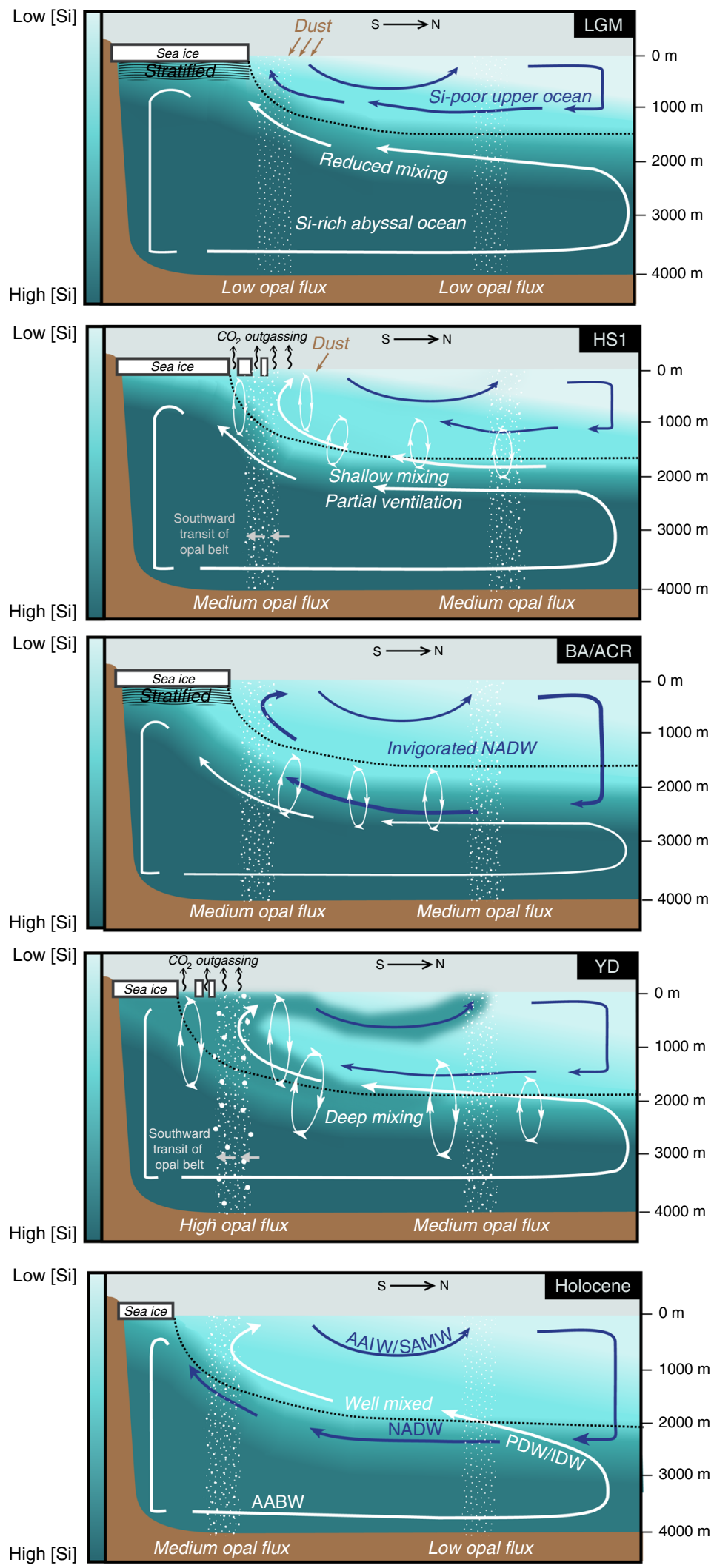

Fig. 5 A schematic representation of the circulation changes and concomitant DSi distribution across the deglaciation. In each panel the upper (NADW/AAIW/SAMW) and lower (AABW/PDW/IDW) circulatory cells are depicted as blue and white arrows, respectively. The shading in each panel represents the concentration of DSi, with the LGM abyssal ocean being more DSi-rich than the modern as a result of reduced mixing. The dotted black line in each of the panels represents the isopycnal at divergence of the upper and lower circulatory cells ${ }^{54}$, the vertical position of which has been suggested to be governed by sea ice extent. Importantly, this schematic demonstrates that only when sea ice is sufficiently removed during the Younger Dryas are the deep Si-rich waters tapped into and redistributed into the upper circulatory cell. Southern Ocean and low latitude opal fluxes are globally generalised based on available data $39,50,81$. 
presented here is that much of the redistribution of DSi appears to have occurred after HS1 when dust-borne iron inputs were low. Therefore, the deglacial leakage was not necessarily assisted by a lower DSi demand by iron-replete diatoms. Secondly, it is argued here that global distribution of DSi is indeed altered between glacial and interglacial states, with an enhancement of DSi concentrations in the deep Pacific as a result of deep stratification. However, we do share the characterization of the deglaciation as an interval of massive DSi leakage, but primarily as a product of the reconfiguration of the global DSi distribution between the glacial and interglacial states.

Changes in the distribution of DSi have important implications for the biological pump and thus atmospheric $\mathrm{CO}_{2}{ }^{36,67,68}$. On an initial assessment, the accumulation of DSi in the abyssal ocean (and removal of DSi from the upper ocean) during glacials as described above would appear to favour the initiation of a negative feedback similar to that described by Dugdale et al. ${ }^{69}$, in which the decline in $\mathrm{CO}_{2}$ during glaciations is limited by an decrease in the $\mathrm{C}_{\text {org }}: \mathrm{CaCO}_{3}$ rain ratio as diatoms are replaced by calcifiers in the DSi-depleted upper ocean.

However, the lack of an apparent reduction in diatom production in many regions ${ }^{70-72}$ and the lower DSi utilization in many parts of the glacial world ocean ${ }^{35,50,73}$ suggest that an ecosystem shift away from diatom-dominance as a result of declining DSi availability was curtailed. This may have been achieved by a reduction in DSi uptake by diatoms through a combination of iron-induced alteration of diatom Si:C stoichiometric demand ${ }^{74,75}$ as well as a reduction in biogenic silica export in the more extensively ice-covered waters of the glacial Antarctic ${ }^{76,77}$ allowing more DSi to be used in lower latitudes. Hence, we invoke the processes behind the silicic acid leakage hypothesis to help mitigate against the sequestration of DSi into the deep ocean by permitting a greater proportion of the DSi upwelled to the Southern Ocean to leak to lower latitudes thus sustaining diatom growth ${ }^{24}$.

A complete depletion of DSi in the upper ocean may have also been partially alleviated by an increase in the whole-ocean inventory of DSi, thus allowing the deep ocean DSi content to rise while maintaining a sufficiently large DSi pool in the upper ocean. Indeed, the higher DSi content of the Pacific as interpreted from $\delta^{30} \mathrm{Si}_{\text {sponge }}$ and sponge $\mathrm{Ge}: \mathrm{Si}$ data ${ }^{47,78}$ without a concomitant reduction elsewhere provide evidence for a larger oceanic DSi inventory during the LGM. This interpretation is further supported by a compilation of global opal flux data presented in Supplementary Table 4 and Supplementary Note 6 that on average exhibit enhanced opal burial during the deglaciation. The total terrestrial DSi input into the ocean is thought to have decreased across the deglaciation ${ }^{79}$, therefore the enhanced opal burial during the deglaciation would lower the global oceanic DSi inventory during the climatic transition. The higher glacial DSi inventory may have been driven by a combination of greater terrestrial input ${ }^{79}$ and reduced opal burial in response to sea ice cover in the Antarctic 80,81 and reduced silicification of ironreplete diatoms ${ }^{36}$.

Although the evidence given above suggests that glacial wholeocean $\mathrm{Si}$ inventory increased, this may not have benefited diatom production in the surface ocean in its entirety and would have at least partially offset the tendency for DSi sequestration in the abyssal ocean due to deep ocean stratification. On balance, we suggest that the lower DSi demand by diatoms due to $\mathrm{Fe}$ fertilization combined with a greater DSi inventory maintained at least a similar degree of diatom dominance within glacial phytoplankton communities compared to interglacials. Consequently, the average $\mathrm{C}_{\text {org }}$ : $\mathrm{CaCO}_{3}$ rain ratio, which is influenced by the relative dominance of silicifying plankton such as diatoms over calcifying plankton, would not have decreased or may have even increased ${ }^{24}$. This could have enabled continued sequestration of carbon into the deep ocean through glacial periods and a concomitant decline in atmospheric $\mathrm{CO}_{2}$ to its lowest levels observed during the Cenozoic ${ }^{82,83}$.

Our new results reveal the global-scale reconfiguration in the marine Si cycle between glacial and interglacial periods as a result of both ocean circulation changes responsible for DSi supply to the surface ocean and changes in the bio-geochemical cycling of $\mathrm{Si}$ by diatoms and the associated shifts in $\mathrm{C}$ and Si stoichiometry of the biogenic export fluxes under variable iron concentrations. Our study also suggests that the timing of $\mathrm{CO}_{2}$ release from the abyss, which occurred in two stages $(\sim 18-14.5 \mathrm{ka} \text { and } 13-11.5 \mathrm{ka})^{6,8}$ was decoupled from the release of $\mathrm{Si}$, which occurred primarily during the YD (13-11.5 ka). This decoupling is attributed to the deeper regeneration depth of $\mathrm{Si}$ relative to $\mathrm{C}$ causing the $\mathrm{Si} C \mathrm{C}$ ratio of upwelling water to be dependent on vertical mixing and deep stratification. Given these finding, what role did the reorganisation of the Si cycle play in glacial-interglacial changes in $\mathrm{CO}_{2}$ ?

We propose that glacial stratification acts to progressively strip DSi from the surface ocean. This reduces the efficiency of the biological pump in the surface ocean, counteracting the impact of carbon sequestration in the deep ocean. However, the reduced efficiency of the biological pump is moderated by the decrease in Si:C uptake by diatoms due to additional iron supply $24,36,66$. A higher glacial Si inventory may also have played a role in this process $47,77,78$. Collectively, this allowed atmospheric $\mathrm{CO}_{2}$ concentrations to remain lower during glacial periods. Conversely, the release of DSi from the abyss at glacial terminations would have increased the availability of DSi for diatom production in the upper ocean (Fig. 3). This should have increased the efficiency of the biological pump and limited the rise in atmospheric $\mathrm{CO}_{2}$. However, the biological pump is moderated by a greater $\mathrm{Si}: \mathrm{C}$ use by diatoms under reduced Fe availability allowing relatively high $\mathrm{CO}_{2}$ levels to be maintained during warm periods ${ }^{36,66}$. Therefore, we propose that ocean circulation and stratification to a large extent determine the timing of $\mathrm{CO}_{2}$ release during glacialinterglacial transition; however, the concomitant $\mathrm{Si}$ cycle changes is part of the tightly coupled biological feedback mechanism that determines the magnitude and sets the limits on glacialinterglacial variability in atmospheric $\mathrm{CO}_{2}$ concentrations across the Pleistocene.

\section{Methods}

Setting. Piston cores MD84-551 (55.01으, $73.17^{\circ} \mathrm{E}, 2230 \mathrm{~m}$ water depth), MD88$773\left(52.90^{\circ} \mathrm{S}, 109.87^{\circ} \mathrm{E}, 2460 \mathrm{~m}\right.$ water depth) and $\mathrm{MD} 88-772\left(50.02^{\circ} \mathrm{S}, 104.90^{\circ} \mathrm{E}\right.$, $3240 \mathrm{~m}$ water depth) were retrieved by the Marion Dufresne in the Indian sector of the Southern Ocean. MD84-551 is situated on the south-western flank of the Kerguelen Plateau, MD88-773 and MD88-772 are both located on the southern flank of the South-East Indian Ridge.

\footnotetext{
$\boldsymbol{\delta}^{\mathbf{3 0}} \mathbf{S i}_{\text {diat. Isolated diatom samples were produced from bulk sediment through }}$ mechanical separation and chemically cleaning following that of Morley et al. ${ }^{84}$ using a size fraction of $10-75 \mu \mathrm{m}$. The quality of the cleaning procedure was assessed by inspection through scanning electron microscopy. The procedure produced samples that appeared to contain $>98 \%$ diatoms, with the remaining fraction consisting of silicoflaggelates, radiolaria fragments and sponge spicule fragments. The clay fraction was reduced such that $<0.5 \%$ of the surface area of samples inspected by SEM were clay.

The method for $\delta^{30} \mathrm{Si}$ analysis follows that of Georg et al. ${ }^{85} .10 \mathrm{ml}$ of cleaned diatoms suspended in Milli-Q water were digested in $0.1 \mathrm{M}$ suprapure $\mathrm{NaOH}$ before neutralisation with $1 \mathrm{M}$ double-distilled $\mathrm{HCl}$ and dilution to $20 \mathrm{ppm} .0 .5 \mathrm{ml}$ of the DSi analyte was then loaded into a pre-cleaned $1.8 \mathrm{ml}$ BioRad AG 50W-X8 cation exchange resin column and eluted with Milli-Q water. Isotopic compositions of samples were analysed by MC-ICP-MS on a Nu Plasma II instrument at the University of Edinburgh using sample-standard bracketing with isotopic reference material, NBS28. All $\delta^{30} \mathrm{Si}$ values quoted are with respect to NBS28. Average internal reproducibility at $1 \mathrm{SE}$ is $0.06 \%$ o ( $n \geq 3$ per sample, total 124 samples including repeats) and is displayed as error bars in Fig. 2. Average external reproducibility is $0.09 \%$ ( $n \geq 3$ per sample, total 14 samples).
} 
$\delta^{30} \mathbf{S i}_{\text {sponge. }}$ Sponge spicules were hand-picked from chemically cleaned and mechanically separated bulk sediment through the same method as the diatoms above using a size fraction of $>75 \mu \mathrm{m}$. Due to the scarcity of spicules within some sediment layers, multiple sampling intervals were combined and plotted as horizontal error bars in Fig. 3d. The method for $\delta^{30} \mathrm{Si}$ analysis is identical to the $\delta^{30} \mathrm{Si}_{\text {diat }}$ method given above.

Opal. The percentage opal content by dry weight of bulk sediment samples was determined via dissolution in $\mathrm{NaOH}$ and the heteropoly blue method (also referred to as the molybdenum-blue method) ${ }^{86}$. Opal fluxes were produced using the ${ }^{230} \mathrm{Th}$-normalisation method ${ }^{38}$. Excess ${ }^{230} \mathrm{Th}$ used to perform the ${ }^{230} \mathrm{Th}-$ normalisation was determined by acid digestion of bulk samples followed by anion exchange column chemistry and isotope dilution inductively coupled plasma mass spectrometry ${ }^{87-90}$

Age models. Where possible, the age models for the three cores were constructed based on accelerator mass spectrometry ${ }^{14} \mathrm{C}$ data, with analysis performed at the NERC Radiocarbon Laboratory, East Kilbride. ${ }^{14} \mathrm{C}$ ages were calibrated using the Calib 7.04 software with the Marine13 calibration curve. Reservoir effects were applied to the dates, see Supplementary Note 1 for more details. Poor $\mathrm{CaCO}_{3}$ preservation prevented the use of ${ }^{14} \mathrm{C}$ dating for MD88-773 and MD88-772 during the early deglaciation and LGM. The age models at these intervals were constructed by graphical correlation of titanium with detritus fluxes in nearby ${ }^{14} \mathrm{C}$-dated sediment cores (see Supplementary Note 1, Supplementary Tables 1-3 and Supplementary Figs. 2 and 3 for more details).

\section{Data availability}

The data that support the findings of this study are available in the PANGAEA database https://doi.org/10.1594/PANGAEA.911189 [https://doi.pangaea.de/10.1594/ PANGAEA.911189] $]^{91}$.

Received: 27 June 2019; Accepted: 14 February 2020;

Published online: 24 March 2020

\section{References}

1. Monnin, E. et al. Atmospheric $\mathrm{CO}_{2}$ concentrations over the last glacial termination. Science 291, 112-114 (2001)

2. Toggweiler, J. Variation of atmospheric $\mathrm{CO}_{2}$ by ventilation of the ocean's deepest water. Paleoceanography, 14. (1999).

3. Jacobel, A. W. et al. Repeated storage of respired carbon in the equatoria Pacific Ocean over the last three glacial cycles. Nat. Commun. 8, 1727 (2017).

4. Talley, L. D. Closure of the global overturning circulation through the Indian, Pacific and Southern Oceans: schematics and transports. Oceanography 26, 80-97 (2013)

5. Skinner, L. C. et al. Ventilation of the deep Southern Ocean and deglacial CO2 rise. Science 328, 1147-1151 (2010).

6. Burke, A. \& Robinson, L. F. The Southern Ocean's role in carbon exchange during the last deglaciation. Science 335, 557-561 (2012).

7. Siani, G. et al. Carbon isotope records reveal precise timing of enhanced Southern Ocean upwelling during the last deglaciation. Nat. Commun. 4, 2758 (2013).

8. Rae, J. W. et al. $\mathrm{CO}_{2}$ storage and release in the deep Southern Ocean on millennial to centennial timescales. Nature 592, 569-573 (2018).

9. Sarmiento, J. L. et al. High-latitude controls of thermocline nutrients and low latitude biological productivity. Nature 427, 56-60 (2004).

10. Moore, J. K. et al. Sustained climate warming drives declining marine biological productivity. Science 359, 1139-1143 (2018).

11. Skinner, L. C. \& Shackleton, N. J. An Atlantic lead over Pacific deep-water change across Termination I: implications for the application of the marine isotope stage stratigraphy. Quat. Sci. Rev. 24, 571-580 (2005).

12. Lisiecki, L. E. \& Raymo, M. E. Diachronous benthic $\delta^{18} \mathrm{O}$ responses during late Pleistocene terminations. Paleoceanography 24, 1-14 (2009).

13. Stern, J. V. \& Lisiecki, L. E. Termination 1 timing in radiocarbon-dated regional benthic $\delta^{18} \mathrm{O}$ stacks. Paleoceanography 29, 1127-1142 (2014).

14. Sikes, E. L., Allen, K. A. \& Lund, D. C. Enhanced $\delta^{13} \mathrm{C}$ and $\delta^{18} \mathrm{O}$ differences between the South Atlantic and South Pacific during the last glaciation: the deep gateway hypothesis. Paleoceanography 32, 1000-1017 (2017).

15. Zhao, N. et al. A synthesis of deglacial deep-sea radiocarbon records and their (In)consistency with modern Ocean ventilation. Paleoceanogr. Paleoclimatology 33, 128-151 (2018).

16. Bostock, H. C. et al. Carbon isotope evidence for changes in Antarctic Intermediate Water circulation and ocean ventilation in the southwest Pacific during the last deglaciation. Paleoceanography 19, 1-15 (2004).
17. Jaccard, S. L. \& Galbraith, E. D. Direct ventilation of the North Pacific did not reach the deep ocean during the last deglaciation. Geophys. Res. Lett. 40, 199-203 (2013)

18. Sikes, E. L. et al. Glacial water mass structure and rapid $\delta 18 \mathrm{O}$ and $\delta 13 \mathrm{C}$ changes during the last glacial termination in the Southwest Pacific. Earth Planet. Sci. Lett. 456, 87-97 (2016).

19. Clementi, V. J. \& Sikes, E. L. Southwest pacific vertical structure influences on Oceanic carbon storage since the last glacial maximum. Paleoceanogr. Paleoclimatology 34, 734-754 (2019).

20. Egge, J. \& Aksnes, D. Silicate as regulating nutrient in phytoplankton competition. Mar. Ecol. Prog. Ser. 83, 281-289 (1992).

21. Dugdale, R. C. \& Wilkerson, F. P. Silicate regulation of new production in the equatorial Pacific upwelling. Nature 391, 270-273 (1998).

22. Buesseler, $\mathrm{K}$. The decoupling of production and particulate export in the surface ocean. Glob. Biogeochem. Cycles 12, 297-310 (1998).

23. Sigman, D. M. \& Boyle, E. A. Glacial/interglacial variation in atmospheric carbon dioxide. Nature 407, 859-869 (2000).

24. Matsumoto, K. \& Sarmiento, J. L. A corollary to the silicic acid leakage hypothesis. Paleoceanography 23, 2 (2008).

25. Ragueneau, O. et al. Si/C decoupling in the world ocean: Is the Southern Ocean different? Deep-Sea Res. Ii. 49, 3127-3154 (2002).

26. De La Rocha, C. L., Brzezinski, M. A. \& DeNiro, M. J. Fractionation of silicon isotopes by marine diatoms during biogenic silica formation. Geochim. Cosmochim. Acta 61, 5051-5056 (1997).

27. Egan, K. E. et al. Diatom silicon isotopes as a proxy for silicic acid utilisation: a Southern Ocean core top calibration. Geochimica Cosmochimica Acta 96, 174-192 (2012).

28. De La Rocha, C. L. et al. Silicon-isotope composition of diatoms as an indicator of diatoms as an indicator of past oceanic change. Nature 395, 28-31 (1998).

29. Hendry, K. R. \& Robinson, L. F. The relationship between silicon isotope fractionation in sponges and silicic acid concentration: Modern and core-top studies of biogenic opal. Geochimica Cosmochimica Acta 81, 1-12 (2012).

30. Hendry, K. R. \& Brzezinski, M. A. Using silicon isotopes to understand the role of the Southern Ocean in modern and ancient biogeochemistry and climate. Quat. Sci. Rev. 89, 13-26 (2014).

31. Cardinal, D. et al. Relevance of silicon isotopes to Si-nutrient utilization and Si-source assessment in Antarctic waters. Glob. Biogeochem. Cycles. 19, GB2007 (2005).

32. Fripiat, F. et al. Silicon pool dynamics and biogenic silica export in the Southern Ocean inferred from Si-isotopes. Ocean Sci. 7, 533-547 (2011).

33. Beucher, C. P., Brzezinski, M. A. \& Crosta, X. Silicic acid dynamics in the glacial sub-Antarctic: implications for the silicic acid leakage hypothesis. Glob. Biogeochem. Cycles 21, 1-13 (2007)

34. Horn, M. G. et al. Southern Ocean nitrogen and silicon dynamics during the last deglaciation. Earth Planet. Sci. Lett. 310, 334-339 (2011).

35. Robinson, R. S. et al. The changing roles of iron and vertical mixing in regulating nitrogen and silicon cycling in the Southern Ocean over the last glacial cycle. Paleoceanography 29, 1179-1195 (2014).

36. Brzezinski, M. A. et al. A switch from $\mathrm{Si}(\mathrm{OH}) 4$ to $\mathrm{NO} 3-$ depletion in the glacial Southern Ocean. Geophys. Res. Lett. 29, 3-6 (2002).

37. Sutton, J. N. et al. Species-dependent silicon isotope fractionation by marine diatoms. Geochimica Cosmochimica Acta 104, 300-309 (2013).

38. Francois, R. et al. ${ }^{230} \mathrm{Th}$ normalization: an essential tool for interpreting sedimentary fluxes during the late Quaternary. Paleoceanography 19, PA1018 (2004).

39. Dézileau, L., Reyss, J. L. \& Lemoine, F. Late Quaternary changes in biogenic opal fluxes in the Southern Indian Ocean. Mar. Geol. 202, 143-158 (2003).

40. Lambert, F. et al. Dust-climate couplings over the past 800,000 years from the EPICA Dome C ice core. Nature 452, 616-619 (2008).

41. Martínez-García, A. et al. Iron fertilization of the Subantarctic ocean during the last ice age. Science 343, 1347-1350 (2014).

42. Fripiat, F. et al. Diatom-induced silicon isotopic fractionation in Antarctic sea ice. J. Geophys. Res. Biogeosci. 112, G02001 (2007).

43. Anderson, R. F. et al. Wind-driven upwelling in the Southern Ocean and the deglacial rise in atmospheric $\mathrm{CO}_{2}$. Science 323, 1443-1448 (2009).

44. Abelmann, A. et al. The seasonal sea-ice zone in the glacial Southern Ocean as a carbon sink. Nat. Commun. 6, 8136 (2015).

45. Hendry, K. R. et al. Abrupt changes in high-latitude nutrient supply to the Atlantic during the last glacial cycle. Geology 40, 123-126 (2012).

46. Meckler, A. N. et al. Deglacial pulses of deep-ocean silicate into the subtropical North Atlantic Ocean. Nature 495, 495-498 (2013).

47. Ellwood, M. J., Wille, M. \& Maher, W. Glacial silicic acid concentrations in the Southern. Ocean. Sci. 330, 1088-1091 (2010).

48. Sarmiento, J. L. et al. Deep ocean biogeochemistry of silicic acid and nitrate. Glob. Biogeochem. Cycles 21, 1-16 (2007). 
49. De Souza, G. F. et al. Silicon stable isotope distribution traces Southern Ocean export of Si to the eastern South Pacific thermocline. Biogeosci 9, 4199-4213 (2012).

50. Pichevin, L. E. et al. Enhanced carbon pump inferred from relaxation of nutrient limitation in the glacial ocean. Nature 459, 1114-1117 (2009).

51. Ronge, T. A. et al. Radiocarbon constraints on the extent and evolution of the South Pacific glacial carbon pool. Nat. Commun. 7, 1-12 (2016).

52. Du, J. et al. Flushing of the deep Pacific Ocean and the deglacial rise of atmospheric $\mathrm{CO}_{2}$ concentrations. Nat. Geosci. 11, 749-755 (2018).

53. Basak, C. et al. Breakup of last glacial deep stratification in the South Pacific. Science 359, 900-904 (2018).

54. Ferrari, R. et al. Antarctic sea ice control on ocean circulation in present and glacial climates. Proc. Natl Acad. Sci. USA 111, 8753-8758 (2014).

55. Curry, W. B. \& Oppo, D. W. Glacial water mass geometry and the distribution of $\delta^{13} \mathrm{C}$ of $\Sigma \mathrm{CO}_{2}$ in the western Atlantic Ocean. Paleoceanography 20, 1-12 (2005).

56. Liu, W. et al. The de-correlation of westerly winds and westerly-wind stress over the Southern Ocean during the Last Glacial Maximum. Clim. Dyn. 45, 3157-3168 (2015).

57. Adkins, J. F. The role of deep ocean circulation in setting glacial climates. Paleoceanography 28, 539-561 (2013).

58. McCave, I. N., Carter, L. \& Hall, I. R. Glacial-interglacial changes in water mass structure and flow in the SW Pacific Ocean. Quat. Sci. Rev. 27, 1886-1908 (2008).

59. Ferry, A. J. et al. First records of winter sea ice concentration in the southwest Pacific sector of the Southern Ocean. Paleoceanography 30, 1525-1539 (2015).

60. Pedro, J. B. et al. The spatial extent and dynamics of the Antarctic Cold Reversal. Nat. Geosci. 9, 51-55 (2015).

61. Xiao, W., Esper, O. \& Gersonde, R. Last Glacial-Holocene climate variability in the Atlantic sector of the Southern Ocean. Quat. Sci. Rev. 135, 115-137 (2016).

62. Mayr, C. et al. Intensified Southern Hemisphere Westerlies regulated atmospheric $\mathrm{CO}_{2}$ during the last deglaciation. Geology 41, 831-834 (2013).

63. Jones, D. C. et al. Spatial and seasonal variability of the air-sea equilibration timescale of carbon dioxide. Glob. Biogeochem. Cycles 28, 1163-1178 (2014).

64. McManus, J. F. et al. Collapse and rapid resumption of Atlantic meridional circulation linked to deglacial climate changes. Nature 428, 834-837 (2004).

65. Barker, S. et al. Extreme deepening of the Atlantic overturning circulation during deglaciation. Nat. Geosci. 3, 567-571 (2010).

66. Ayers, J. M. \& Strutton, P. G. Nutrient variability in Subantarctic Mode Waters forced by the Southern Annular Mode and ENSO. Geophys. Res. Lett. 40, 3419-3423 (2013).

67. Matsumoto, K., Sarmiento, J. L. \& Brzezinski, M. A. Silicic acid leakage from the Southern Ocean: a possible explanation for glacial atmospheric $\mathrm{pCO}_{2}$ Glob. Biogeochem. Cycles 16, 1031 (2002).

68. Harrison, G. Role of increased marine silica input on paleo- $\mathrm{pCO}_{2}$ levels. Paleoceanography 15, 292-298 (2000).

69. Dugdale, R. C. et al. Influence of equatorial diatom processes on Si deposition and atmospheric $\mathrm{CO}_{2}$ cycles at glacial/interglacial timescales.

Paleoceanography 19, PA3011 (2004).

70. Romero, O. et al. Oscillations of the siliceous imprint in the central Benguela Upwelling System from MIS 3 through to the early Holocene: the influence of the Southern Ocean. J. Quat. Sci. 18, 733-743 (2003).

71. Romero, O., Kim, J.-H. \& Donner, B. Submillennial-to-millennial variability of diatom production off Mauritania, NW Africa, during the last glacial cycle. Paleoceanography, 23, PA3218 (2008).

72. Bradtmiller, L. I. et al. Opal burial in the equatorial Atlantic Ocean over the last $30 \mathrm{ka}$ : Implications for glacial-interglacial changes in the ocean silicon cycle. Paleoceanography 22, PA4216 (2007).

73. Maier, E. et al. Deglacial subarctic Pacific surface water hydrography and nutrient dynamics and links to North Atlantic climate variability and atmospheric $\mathrm{CO}_{2}$. Paleoceanography 30, 949-968 (2015).

74. Hutchins, D. A. \& Boyd, P. W. Marine phytoplankton and the changing ocean iron cycle. Nat. Clim. Change 6, 1072-1079 (2016).

75. Takeda, S. Influence of iron availability on nutrient consumption ratio of diatoms in oceanic waters. Nature 393, 774-777 (1998).

76. Bradtmiller, L. I. et al. Comparing glacial and Holocene opal fluxes in the Pacific sector of the Southern Ocean. Paleoceanography 24, 1-20 (2009).

77. Matsumoto, K., Chase, Z. \& Kohfeld, K. Different mechanisms of silicic acid leakage and their biogeochemical consequences. Paleoceanography 29, 238-254 (2014).

78. Jochum, K. P. et al. Whole-Ocean changes in silica and Ge/Si ratios during the last deglacial deduced from long-lived giant glass sponges. Geophys. Res. Lett. 4, 11555-11564 (2017).

79. Frings, P. J. et al. The continental Si cycle and its impact on the ocean Si isotope budget. Chem. Geol. 425, 12-36 (2016).
80. Francois, R. et al. Contribution of Southern Ocean surface-water stratification to low atmospheric $\mathrm{CO}_{2}$ concentrations during the last glacial period. Nature 389, 929-935 (1997).

81. Chase, Z. et al. Accumulation of biogenic and lithogenic material in the Pacific sector of the Southern Ocean during the past 40,000 years. Deep Sea Res. II 50, 799-832 (2003).

82. Zhang, Y. G. et al. A 40-million-year history of A 40-million-year history of atmospheric $\mathrm{CO}_{2}$. Phil. Trans. R. Soc. A 371, 20130096 (2016).

83. Renaudie, J. Quantifying the Cenozoic marine diatom deposition history: links to the C and Si cycles. Biogeosciences 13, 6003-6014 (2016).

84. Morley, D. W. et al. Cleaning of lake sediment samples for diatom oxygen isotope analysis. J. Paleolimnol. 31, 391-401 (2004).

85. Georg, R. B. et al. New sample preparation techniques for the determination of $\mathrm{Si}$ isotopic compositions using MC-ICPMS. Chem. Geol. 235, 95-104 (2006).

86. Mortlock, R. \& Froelich, P. A simple method for the rapid determination of biogenic opal in pelagic marine sediments. Deep Sea Res. A 36, 1415-1426 (1989).

87. Anderson, R. F. \& Fleer, A. P. Determination of natural actinides and plutonium in marine particulate material. Anal. Chem. 54, 1142-1147 (1982).

88. Martínez-Garcia, A. et al. Links between iron supply, marine productivity, sea surface temperature, and $\mathrm{CO}_{2}$ over the last 1.1 Ma. Paleoceanography, 24. (2009).

89. Negre, C. et al. Separation and measurement of $\mathrm{Pa}, \mathrm{Th}$, and $\mathrm{U}$ isotopes in marine sediments by microwave-assisted digestion and multiple collector inductively coupled plasma mass. Anal. Chem. 81, 1914-1919 (2009).

90. Kretschmer, S. et al. Fractionation of ${ }^{230} \mathrm{Th},{ }^{231} \mathrm{~Pa}$, and ${ }^{10} \mathrm{Be}$ induced by particle size and composition within an opal-rich sediment of the Atlantic Southern Ocean. Geochimica Cosmochimica Acta 75, 6971-6987 (2011).

91. Dumont, M. et al. Deglacial diatom and sponge silicon isotope records from cores MD84-551, MD88-773 and MD88-772. PANGAEA https://doi.pangaea. de/10.1594/PANGAEA.911189 (2020).

92. Orsi, A., Whitworth, T. \& Nowlin, W. On the meridional extent and fronts of the Antarctic Circumpolar. Curr. Deep Sea Res. I 42, 641-673 (1995).

93. Garcia, H. E. et al.in World Ocean Atlas 2013, Volume 4: Dissolved Inorganic Nutrients (phosphate, nitrate, silicate). (eds Levitus, S., Mishonov, A. V.) (NOAA Atlas NESDIS 76, 2013).

94. Schlitzer, R. Interactive analysis and visualization of geoscience data with Ocean Data View. Comput. Geosci. 28, 1211-1218 (2002).

95. Rousseau, J. et al. Estimates of late Quaternary mode and intermediate water silicic acid concentration in the Pacific Southern Ocean. Earth Planet. Sci. Lett. 439, 101-108 (2016).

\section{Acknowledgements}

This work was supported by the NERC E3 DTP studentship awarded to M. Dumont and NERC Grant (ne/j02371x/1) award to R.S. Ganeshram and L.E. Pichevin. We would also like to thank S. Mowbray and C. Chilcott from the University of Edinburgh for their invaluable technical assistance. Radiocarbon analyses were supported by the NERC Radiocarbon Facility (allocation 1883.0415).

\section{Author contributions}

This study was conducted as part of a PhD studentship by M. Dumont under the supervision of L.P. and R.G. K.D. performed the $\delta^{30} \mathrm{Si}_{\text {sponge }}$ analyses. W.G. assisted in both the multi-element analyses and Th-normalisation method applied to MD84-551. X.C. provided the diatom assemblage data. E.M. provided the sample material as well as unpublished magnetic susceptibility data. S.M. performed the ${ }^{14} \mathrm{C}$ AMS analysis. M.D. wrote the manuscript and all authors contributed to the redaction.

\section{Competing interests}

The authors declare no competing interests.

\section{Additional information}

Supplementary information is available for this paper at https://doi.org/10.1038/s41467 020-15101-6.

Correspondence and requests for materials should be addressed to M.D.

Peer review information Nature Communications thanks Louisa Bradtmiller and the other, anonymous, reviewer(s) for their contribution to the peer review of this work. Peer reviewer reports are available.

Reprints and permission information is available at http://www.nature.com/reprints

Publisher's note Springer Nature remains neutral with regard to jurisdictional claims in published maps and institutional affiliations. 
(c) (i) Open Access This article is licensed under a Creative Commons Attribution 4.0 International License, which permits use, sharing, adaptation, distribution and reproduction in any medium or format, as long as you give appropriate credit to the original author(s) and the source, provide a link to the Creative Commons license, and indicate if changes were made. The images or other third party material in this article are included in the article's Creative Commons license, unless indicated otherwise in a credit line to the material. If material is not included in the article's Creative Commons license and your intended use is not permitted by statutory regulation or exceeds the permitted use, you will need to obtain permission directly from the copyright holder. To view a copy of this license, visit http://creativecommons.org/ licenses/by/4.0/.

(C) The Author(s) 2020 